\title{
SEM-EDX Analysis of Heavy Metals in Anal Papillae of Hydropsyche Angustipennis Larvae (Trichoptera, Insecta) as a Support for Water Quality Assessment
}

Mariusz Tszydel ( $\sim$ mariusz.tszydel@biol.uni.lodz.pl )

University of Łódź

Dagmara Błońska

University of Łódź

Piotr Jóźwiak

University of Łódź

Małgorzata Jóźwiak

Jan Kochanowski University of Humanities and Sciences

\section{Research Article}

Keywords: bioassay, bioindicator, contamination, morphological abnormalities, sublethal effects, caddisflies

Posted Date: January 21st, 2021

DOl: https://doi.org/10.21203/rs.3.rs-150289/v1

License: (9) This work is licensed under a Creative Commons Attribution 4.0 International License. Read Full License

Version of Record: A version of this preprint was published at The European Zoological Journal on January 1st, 2021. See the published version at https://doi.org/10.1080/24750263.2021.1931490. 


\title{
SEM-EDX analysis of heavy metals in anal papillae of Hydropsyche angustipennis larvae
} (Trichoptera, Insecta) as a support for water quality assessment

\author{
M. Tszydel 1)*, D. Błońska ${ }^{1)}$, P. Jóźwiak ${ }^{2)}$, M. Jóźwiak ${ }^{3)}$
}

1) University of Lodz, Department of Ecology and Vertebrate Zoology, 12/16 Banacha Str., 90237 Lodz, Poland, e-mail address: dagmara.blonska@biol.uni.lodz.pl

2) University of Lodz, Department of Invertebrate Zoology and Hydrobiology, 12/16 Banacha Str., 90-237 Lodz, Poland, e-mail address: piotr.jozwiak@biol.uni.lodz.pl

3)Jan Kochanowski University of Humanities and Sciences, Department of Environment Protect and Modelling, 15 Świętokrzyska Str., 25-406 Kielce, Poland, e-mail address: malgorzata.jozwiak@vp.pl

*corresponding author: Mariusz Tszydel, Department of Ecology and Vertebrate Zoology, University of Lodz, 12/16 Banacha Str., 90-237 Lodz, Poland, e-mail address: mariusz.tszydel@biol.uni.lodz.pl

\section{Abstract}

Anal papillae of caddisflies are peripheral organs responsible for osmoregulation and detoxification. Investigation of morphological abnormalities in the anal papillae of Hydropsyche angustipennis enriched with using SEM-EDX analysis (scanning electron microscopy-energy dispersive X-ray analysis), was used to assess heavy metal pollution levels in urban streams receiving surface runoff. Heavy metal ions not previously detected in water and tissue samples were detected using SEM-EDX method. Morphological irregularities were most frequently observed in larvae from the most contaminated streams. Heavy metals were almost 10 times more concentrated in darkened papillae than in pale, normal-shaped papillae. The present study 
confirms that SEM-EDX microscopy is an effective method as a support of standard heavy metal

27 bioassays, especially if there is a necessity to detect trace elements in very low concentrations or

28 incidental appearance of some ions in the water.

30 Key words: bioassay, bioindicator, contamination, morphological abnormalities, sublethal

31 effects, caddisflies

\section{Introduction}

34 The assessment of pollution impact on aquatic ecosystems is usually based on both physical and 35 chemical analysis of water quality and biomonitoring of living organisms. However, the emphasis 36 in evaluation of the environment pollution of surface water has been recently shifted to 37 monitoring of bioindicator species [1, 2]. Among traditionally used bio-indices, a majority are 38 founded on taxonomic differentiation of aquatic invertebrates or multispecies assemblages' 39 sensitivity in response to human-induced stressors [3]. Also morphological [4] or behavioural [5, 40 6] changes in comprehensively studied species, that are caused by modifications of environment 41 quality, may turn out to be as exploitable as traditional biotic indices [7]. The using of individual

taxons as one-species universal bioindicators is gaining more and more attention in assessment of aquatic pollution.

One of the main purposes of the current policy (e.g. Water Framework Directive (Directive 2000/60/EC) in EU) is the protection and improvement of aquatic environment in all types of surface waters. The protection programme also applies to highly modified, polluted urban streams, usually inhabited only by eurytopic species $[8,9]$. The wide tolerance range of these organisms limits their usefulness in pollution assessment $[10,11]$. On the other hand, such less sensitive species, resistant to substantial changes of water quality, may be used for detection of dangerous pollutants e.g. heavy metals, as non-destructive environmental bioindicators [12]. 
Evaluation of heavy metals pollution is often based on the assumption that metals can accumulate in organism tissues, which reflect the environment contamination [13, 14]. Such bioaccumulation-based methods may also effectively track elements, which are often in concentrations below detection limits [7]. However, the obtained results may not reflect the water quality conditions correctly, because organisms show diverse levels of assimilation, detoxification, metal tolerance and active absorption/removal of particular elements [14]. Discrepancies may appear when heavy metals are being excessively assimilated from sediment [15], adsorbed on the body surface [16] or accumulated in subsequent trophic levels [17]. Higher levels of heavy metals concentration are observed in early larval stages, in which the detoxification system is not fully developed. On the other hand, several larval stages in the life cycle result in lower levels of contamination [18].

Morphological abnormalities of bioindicator species offer another useful tool for pollution assessment, reflecting metal exposure conditions via element concentrations in organism tissues (16). Body deformations should be clearly visible, easy to compare with not contaminated individuals and irreversible even after ceasing the pollution, but simultaneously not lethal (therefore, they are often referred to as "sublethal effects") [19-21]. Depending on species, such changes may consist of irregularities e.g. in the head capsule structure, mouthparts, tracheal gills or anal papillae [3]. In case of caddisflies, morphological abnormalities are usually connected with changes in water chemistry and based on the analysis of tracheal gills and anal papillae structure $[16,22]$. Larvae of Hydropsychidae seem to be a promising tool in biomonitoring of surface waters, especially for streams flowing through urbanized areas [7 - 9]. They are widely distributed and resistant to chemical and physical modifications of stream environments. The presence of heavy metals in water manifest itself in their accumulation in larvae tissues as well as in anal papillae abnormalities such as darkeninig and constricting [7, 16, 22]. It is suggested that anal papillae become darkened due to accumulation of heavy metals in the epithelium. The degree 
76 of such morphological irregularities in response to water pollution changes gradually, which can

77 be particularly informative [16].

In our previous studies, we have also observed suggested correlation between heavy metal

79 contamination in water and tissue samples, and sublethal effects leading to morphological

80 changes in anal papillae [7, 23]. However, due to small sizes of anal papillae (2-3 $\mathrm{mm})$ it has not

81 been tested for heavy metal accumulation so far. In the present study, our aim was to directly

82 confirm that this particular organ (anal papillae) has an ability to accumulate heavy metals and

83 depending on the level of contamination we will be able to record progressing changes in anal

84 papillae. The method most often used for tissue analysis, such as AAS (Atomic Absorption

85 Spectrometry) was not possible to apply in this research due to small sizes of the tested organ.

86 Thus, we used SEM-EDX analysis, technique enabling qualitative identification of all trace

87 elements in the tested sample, even such small sizes. By SEM-EDX microscopy analysis, we

88 were also able to compare particular parts of anal papillae e.g. pale with darkened ones. We

89 supplemented the analysis of particular elements presence with visual observations of anal

90 papillae in search for possible morphological irregularities and further correlations. We aimed to

91 prove that this organ can serve as an effective tool in water quality assessment, especially at the 92 screening stage, as its state can be verified intravitally and it indicates the effect through 93 accumulation of contaminants.

$94 \quad 2 . R e s u l t s$

$95 \quad$ 2.1. Sublethal effects of anal papillae

96 Analysed individuals had various stages of irregularities. Subsequent darkening of anal papillae 97 was observed as well as larvae with two out of four papillae darkened. Part of specimens had all 98 papillae darkened partially - only at the top of papillae or black rings (circuited in black) around 99 papillae (Fig. 2b, 3a). In larvae with all papillae darkened completely also structural deformation 00 (rugosity/shrinking) of papillae was observed, which is the final mark of degradation (Fig. 2c). 
01 Such changes were recorded in larvae from the L1-RC and O3-IC sampling sites. At the reference 02 sites (B1-NS and G1-NS), in almost half of the individualsthe anal papilae were not even 03 protruded outside the last abdominal segment (Fig. 5). Only a small percentage of larvae had 04 partially (COLRAP +/-) or completely darkened (COLRAP) papillae (8-11\% and less than $10 \%$, 05 respectively). An opposite situation was observed in samples from streams flowing through the 06 city center and included in the sewage system, where most individuals had morphological 07 abnormalities. In larvae collected from the Rivers Sokołówka and Olechówka (S1-IC and S2-NS, 08 O1-RS and O2-IC, respectively) less than $30 \%$ of specimens had no changes in anal papillae, 09 while this value for larve at the L1-RC sampling site amounted to only $2 \%$. Mean values of the 10 observed abnormalities differed among sampling sites within each category: PALE $11 \quad\left(\mathrm{~F}_{\mathrm{ANOVA}(7,24)}=3.7705\right.$ and $\left.p_{\mathrm{ANOVA}}<0.0068\right)$, COLRAP $+/-\left(\mathrm{F}_{\mathrm{ANOVA}(7,24)}=9.1353\right.$ and $\left.p_{\mathrm{ANOVA}}<0.0000\right)$ and $12 \operatorname{COLRAP}\left(\mathrm{F}_{\mathrm{ANOVA}(7,24)}=2.2101\right.$ and $\left.p_{\mathrm{ANOVA}}<0.0498\right)$ (Fig. 5). The values for individual categories in 13 Fig. 5 did not sum up to $100 \%$, as some of the larvae did not have any visible/exposed anal 14 papillae..

\section{$15 \quad$ 2.2. Heavy metals in anal papillae}

Analysis of heavy metal concetration in anal papillae revealed the presence of 11 elements. Summarised mean values of concentration of heavy metals in anal papilae cuticula did not exceed $10 \%$ at any of sampled stations (Table 1 ). Heavy metal domination in anal papillae was presented in increasing order $\mathrm{Fe}>\mathrm{Mo}>\mathrm{Mn} \geq \mathrm{Al}>\mathrm{Cu}>\mathrm{Pb} \geq \mathrm{Ni}>\mathrm{Co} \geq \mathrm{As} \geq \mathrm{Ti} \geq \mathrm{V}$ (Table 1). The lowest values for most elements were recorded for reference sites flowing beyond the city center (G1-NS and B1NS). Iron reached maximum values (13\%) in papillae from larvae collected at the S1-IC sampling site and dominated in the papillae of larvae from O2-IC and L1-RC (Table 1). Aluminium was detected in larvae papillae at all sampling sites (highest values L1-RC) and it was the only element recorded at reference site G1-NS, although sometimes below the accepted detection limit. Most of investigated elements, even nickel, were observed in anal papillae collected at the 
26 sampling site localized near the railway siding O2-IC. Considering mean values of heavy metal 27 concentrations in anal papillae, sampling sites differed significantly $\left(\mathrm{F}_{\mathrm{ANOVA}(7,51)}=5.7109\right.$ and $28 p_{\mathrm{ANOVA}}<0.0001$ ), which results from discrepancy among values of $\mathrm{Fe}, \mathrm{Mo}, \mathrm{Mn}$ and $\mathrm{Al}$ and total 29 surface load of heavy metals (Table 1). In both pale and darkened papillae, similar elements were 30 recorded, however, in different concentrations and dominance $\left(\mathrm{F}_{\mathrm{ANOVA}(2,56)}=20.0931\right.$ and $31 p_{\text {ANOVA }}<0.0000$ ) (Fig. 6). For protruded, but not darkened papillae (PALE) mean values were ten 32 times lower compared to completely darkened ones (COLRAP). In case of partially and totally 33 darkened papillae, the order of leading heavy metals was similar and as follows: $\mathrm{Fe}>\mathrm{Mn}>\mathrm{Mo}>\mathrm{Al}$ 34 and $\mathrm{Fe}>\mathrm{Mo}>\mathrm{Mn}>\mathrm{Al}$, respectively. For $\mathrm{PALE}$, the order was different: $\mathrm{Al}>\mathrm{Cu}>\mathrm{Ni}>\mathrm{Fe}>\mathrm{Pb}$ (Fig. 6).

\section{3. Discussion}

Heavy metal concentration in hydropsychid larvae commonly corresponds to the

contamination of water and sediment, regardless of whether the source of pollution was urbanization, industry [16, 24, 25] or agriculture [26]. H. angustipennis, like other representatives of this family $[27,28]$, are metallotolerant organisms and capable of accumulating heavy metals in the body tissues even if the elements' concentrations in the environment are below the detection level $[7,23]$. Although there is usually a positive relationship between the presence of heavy metals in the water and the same elements accumulated in the body tissues, it may not always be true for all the elements detected. The presence of a particular heavy metal in the larval bodies may result from the rate of assimilation of the element and the removal efficiency when its concentration becomes toxic $[18,24,29,30]$, the duration of exposure to pollution $[7,23]$ and the feature of bottom sediments [31]. Exposed to pollution, organisms respond in various ways. For aquatic insect larvae, which possess anal papillae, the organ serves as a regulatory and supportive in detoxification. Their epithelium is covered with a structure of highly concentrated, specialized cells for osmoregulation via active and passive transport of ions $[3,32]$. In these cells heavy metals can be bonded and precipitated by metallothioneins [33, 34]. Darkening and deformation 
51 of anal papillae due to water contamination appear when heavy metal and metaloid concentrations 52 in the environment exceed physiological ion exchange ability [16]. Morphological abnormalities 53 in the anal papillae of Hydropsyche spp. in response to water pollution, also in contact with heavy 54 metals, were observed under laboratory conditions [16, 22, 35] as well as in the field [7, 36]. 55 Analysis of such deformities in natural conditions can be applied especially, when contamination 56 persists for several days, regardless of its concentration [37], though even short-time high 57 concentrations of heavy metals can cause morphological abnormalities [20]. The observed 58 deformities of anal papillae progress gradually, dependent on the intensity of contamination, and 59 are irreversible [19]. Aquatic invertebrates have other structures with a 'long memory' of water 60 pollution as the epithelium of the middle intestine, the Malpighian tubules or adipose tissue [5] 61 but only anal papillae, as an external organ, are possible to investigate intravitally. The 62 appearance of visible changes in anal papillae of $H$. angustipennis larvae may be the first sign for 63 further environmental investigation.

Physicochemical research conducted on streams within the Łódź city revealed the 65 presence of various heavy metals in the water samples, $\mathrm{Zn}>\mathrm{Cu}>\mathrm{Pb}>\mathrm{Cd}[7,23,38,39]$, in the insects, $\mathrm{Fe}>\mathrm{Zn}>\mathrm{Pb}>\mathrm{Cu}>\mathrm{Mn}>\mathrm{Ni}>\mathrm{Cd}>\mathrm{Cr}[7,23,43]$. In the present study, in anal papillae Al, Mo, bottom sediments, $\mathrm{Zn}>\mathrm{Cu}>\mathrm{Pb}>\mathrm{Mn}>\mathrm{Ni}>\mathrm{Cr}>\mathrm{Cd}[40-43]$, and in the body tissues of aquatic Co, As, Ti and $\mathrm{V}$ were also recorded. None of these elements were detected in previously mentioned studies, thus it is difficult to assess if they were available in the water, might contribute by food uptake, are the result of omitting these elements at the stage of setting up the analysis device or of trace amounts not exceeding the detection threshold. However, in the mentioned studies different methodology was applied (AAS with flame atomization or non-flame atomization in a graphite tube atomizer). Taking into account that SEM-EDX is a qualitative method it is not possible to directly compare the results with quantitative methods such as AAS. Nevertheless, based on the obtained results, element dominance can be ordered, and this 
dominance trend can be compared. The results are usually presented as a percentage of a given element in the examined tissue, which in the case of anal papillae should be understood as the dominance of the occurrence in the environment [44], which a larva was trying to neutralize in the body [33]. Some elements, even in very low concentrations, may be toxic to aquatic organisms, and therefore their detection is important from the monitoring point of view. This may be the case of the aluminum, arsenic and vanadium, which even in a low concentration in water, can be toxic and may contribute to various types of abnormalities in aquatic organisms [37].

SEM-EDX microscopy confirmed that darkened and deformed papillae had higher concentrations of heavy metals than pale one. This explains why the sub-lethal effects observed in these organs are more common in the contaminated waters [7]. SEM-EDX method proved to be a valuable support in environmental studies, especially the one, in which caddisfly larvae $H$. angustipennis meet most of expectations and can serve as a heavy metal bioindicator in urban streams. Using the representative of the same species, at the same stage of development, which has been exposed for a long time to contaminated water, the possible discrepancies of bioaccumulation $[7,45,46]$ and underestimation related to increased temporary metallotolerance $[47,48]$ will not have such a significant impact on the objectivity of water quality assessment. Although SEM-EDX does not give quantitative results, it allows to indicate to which heavy metals and metalloids the body has been exposed. In anal papillae, heavy metals are accumulated to inactive form, while analyzing these elements in the tissues is burdened by their active management in the body. The SEM-EDX method was confirmed to be valuable also for various freshwater [49, 50], marine [51] and terrestrial insects [52]. It seems that this method could be particularly useful in the screening study, in which it enables to identify all the trace elements present in the sample and indicate the direction for further detailed studies. The SEM-EDX analysis could also indicate, point short-term discharges of sewage, which cannot always be 
00 captured by taking a water sample for analysis, as after ceasing the pollution accumulated

01 elements will be possible to trace in detoxification organs.

\section{4. Materials and methods}

03 4.1. Study area

04 The study was conducted in streams located in the city of Łódź (central Poland). In 05 contrast to most other large cities, Łódź is not situated on a single large river, but has a channel 06 network consisting of almost 30 small streams. Sampling sites were established so that they do 07 not differ in terms of basic environmental parameters, but only in the degree of human-mediated 08 stream bed modification and the level of water pollution (Fig. 1). Detailed characteristics of the 09 sampling sites were included in Tszydel et al. [7]. Seven out of the eight sampling sites were 10 located within the city (on the rivers Bzura, Sokołówka, Łódka and Olechówka). Two reference 11 sites were assigned for the river network of the Łódź agglomeration, one located on the outskirts 12 of the Łódź city, in the Bzura River (B1-NS), and the other one in the Grabia River running 13 outside the urban area (G1-NS) (Fig. 1). Alterations of streambeds as well as potential sources of 14 pollution are shown in Fig. 1.

\section{4.2. Heavy metal analysis in anal papillae}

Samples were taken once a month from March till June 2011, just after winter thaws

17 and spring heavy rains. At each sampling site 30 larvae individuals of $H$. angustipennis in the full18 grown, fifth instar were taken (collected from stones and available objects immersed in water; 19 hand sorted). Specimens were rinsed twice with deionized water in order to remove 20 contamination from the body surface and stored in $70 \%$ ethanol. In the laboratory, before heavy 21 metal evaluation, larvae were photographed (Nikon SMZ 1000 and OptaTech HD digital camera)

22 for anal papillae morphological comparisons (Fig. 2a-c). In H. angustipennis there are always 23 four anal papillae. In unpolluted streams, this organ is invisible, hidden in the last ( $\left.9^{\text {th }}\right)$ abdomen 24 segment [53]. In response to increasing contamination, papillae start to grow and begin to 
protrude outside as white or pale finger-shaped structures (marked as PALE; Fig. 2a) to function more efficiently [32]. Larvae with partially darkened anal papilae were marked as COLRAP +/-

(Fig. 2b) and those completely darkened as COLRAP (Fig. 2c). Presence of pale papillae, as well as its darkening and structural changes, were assigned as morphological abnormalities of anal papilae. For each category mean values of the percentage of larvae with irregularities compared to all collected specimens were indicated for particular sampling term and site. Only the most advanced/last larvae stage $\left(5^{\text {th }}\right.$ instar) was taken into the analysis. Larvae stages were identified based on our experience, however, in case of any doubts, we used the keys Edington and Hildrew [53] as well as Hildrew and Morgan [54], where particular species ranges of head capsule and other diagnostic features for each larval stadium are provided. In the temperate climate zone, $5^{\text {th }}$ instar stage is present in the water the longest and the larvae collected for the study were the last molting at least 3 months earlier. Thus, the process of the larval molting did not influence the assessment of darkening. After a visual observation and taking a photograph of the larvae, the last abdominal body segments were dissected for SEM-EDX analysis. We have randomly selected 10 individuals with visible anal papillae (at least one papillae). Samples were then placed in $2 \%$ glutaraldehyde and dehydrated in graded ethanol concentrations (30-96\%) and acetone. In order to remove water from the samples and avoid deformation, critical point dryer (POLARON CPD), was used. For microscope examination, the samples were coated with carbon and gold in a vacuum sprayer (JEOL JEE 4C vacuum evaporator). Papillae were then mounted to the pins with double-sided adhesive carbon tape, keeping their position parallel to the pin surface. The approximate thickness of papillae at the analysis points is only $1 \mathrm{~mm}$ in diameter and thus it is not limiting the SEM-EDX analysis or causing analysis errors. Elemental analyses were carried out with FEI QUANTA 250 scanning electron microscope (FEI Company) equipped with energydispersive X-ray spectroscopy module (EDX) [55]. Measurements were carried out at three different measuring points (Fig. 3a), then the results were averaged for individual categories of 
50 the sub-lethal effects. In case of papillae classified as COLRAP and COLRAP +/-, only darkened

51 places were analyzed. The samples were analysed using always the same tilt angle $-0^{\circ}$ (approx. $5290^{\circ}$ take-off angle) and with the accelerating voltage set to $30 \mathrm{kV}$. We used $0.1 \%$ as the detection 53 limit for the EDX analysis [56]. EDX detectors collected a spectrum for every pixel of the frame. 54 The spectra were then processed into a set of element intensity maps and analysed using 55 MultiSpec $\mathbb{C}$ [57], a multispectral image analysis software, in which a clustering algorithm is used 56 to identify and quantify groups of mutually exclusive chemical compositions. EDX analysis is 57 generally used for qualitative assessment of particular elements, however, the method can have 58 wider application [56].

59 In our case, the system provided information on the qualitative chemical composition of a sample, 60 showing the weight percentage and atomic percentage for each element of interest in a given point 61 on the SEM image (Fig. 3b). For each point, three measurements were made and those from 62 which a repetitive spectrum was obtained were implemented. The EDX spectra obtained for one 63 of the point analyses are shown in Fig. 4. Before the EDX analysis of the biological material 64 tested, the microscope operating conditions and microanalytical parameters were set. These 65 included specifying microscopic parameters related to detector geometry and system calibration. 66 Calibration was performed whenever the curve in the HPD (Halographic Peak Deconvolution) 67 profile did not coincide with the spectrum profile for the main peaks. The calibration method uses 68 spectral lines for $\mathrm{AlK}$ and $\mathrm{CuK}$. To identify the spectrum, the HPD function was used to collect 69 spectra and generate a theoretical spectrum for comparison with the resulting set of spectra. Only 70 peaks in which the collected peaks were superimposed on the theoretical peaks were accepted 71 (Fig. 4).

\section{4.3. Data analysis}

73 All analyses were performed with the use of STATISTICA software system version 10 [58]. 74 Kolmogorov-Smirnov test with Lilliefors correction were used to test for normality. To 
75 standardize and stabilize the distribution of variance the logarithmic transformation of variables $76\left(\log _{10}(\mathrm{x}+1)\right)$ was made [59, 60]. One-way ANOVA test (preceded by Levene's test) was 77 performed in comparisons: between concentration of heavy metals in anal papillae as well as 78 deformities of anal papillae. In all statistical analyses, the level of significance was equal to $p<$ $790.05[61]$.

81 The dataset generated and analyzed during the current study are available from the corresponding 82 author on reasonable request.

\section{References}

1. Rochfort, Q., Grapentine, L., Marsalek, J., Brownlee, B., Reynoldson, T., Thompson, S., Milani, D. \& Logan, C. Using benthic assessment techniques to determine combined sewer overflow and stormwater impacts in the aquatic ecosystem. Water Qual. Res. J. Can. 35, 365397 (2000).

2. Wright, J. F. An introduction to RIVPACS in Assessing the biological quality of fresh waters: RIVPACS and other techniques (eds. Wright, J. F., Sutcliffe, D. W. \& Furse M. T.) 1-24 (Freshwater Biological Association, Cumbria, 2000).

3. Kefford, B. J., Reddy-Lopata, K., Clay, K., Hagen, T., Parkanyi, O. \& Nugegoda, D. Size of anal papillae in chironomids: Does it indicate their salinity stress? Limnologica 41, 96-106 (2011).

4. Lenat, D. R. Using mentum deformities of Chironomus larvae to evaluate the effects of toxicity and organic loading in streams. J. N. Am. Benthol. Soc. 21, 265-269 (1993).

5. Johnson, R. K., Wiederholm, T. \& Rosenberg, D. M. Freshwater biomonitoring using individual organisms, populations and species assemblages of benthic macroinvertebrates in Freshwater Biomonitoring and Benthic Macroinvertebrates (eds. Rosenberg, D. M. \& Resh 
V. H.) 40-125 (Chapman and Hall, New York, 1993).

01

02

03

6. Marqués, M. J., Martínez-Conde, E. \& Rovira, J. V. Effects of zinc and lead mining on the benthic macroinvertebrates of a fluvial ecosystem. Water Air Soil Pollut. 148, 363-388 (2003).

7. Tszydel, M., Markowski, M., Majecki, J., Błońska, D. \& Zieliński, M. Assessment of water quality in urban streams based on larvae of Hydropsyche angustipennis (Insecta, Trichoptera). Environ. Sci. Pollut. Res. 22, 14687-14701 (2015).

8. Bascombe, A. D., Ellis, J. B., Revitt, D. M. \& Shutes, R. B. E. Development of ecotoxicological criteria in urban catchments. Water Sci. Technol. 22, 173-179 (1990).

9. Bonada, N., Vives, S., Rieradevall, M. \& Prat, N. Relationship between pollution and fluctuating asymmetry in the pollution-tolerant caddisfly Hydropsyche exocellata (Trichoptera, Insecta). Arch. Hydrobiol. 162, 167-185 (2005).

10. Markert, B., Wappelhorst, O., Weckert, V., Herpin, U., Siewers, U. \& Friese, K. The use of bioindicators for monitoring the heavy-metal status of the environment. J. Radioanalytical Nucl. Chem. 2402, 425-429 (1999).

11. Hilty, J. \& Merenlender, A. Faunal indicator taxa selection for monitoring ecosystem health. Biol. Conserv. 92, 185-197 (2000).

12. Macedo-Sousa, J. A., Gerhardt, A., Brett, C. M. A., Nogueira, A. J. A. \& Soares, A. M. V. M. Behavioural responses of indigenous benthic invertebrates (Echinogammarus meridionalis, Hydropsyche pellucidula and Choroterpes picteti) to a pulse of Acid Mine Drainage: A laboratorial study. Environ. Pollut. 156, 966-973 (2008).

13. Hare, L. Aquatic insects and trace metals: bioavailability, bioaccumulation and toxicity. Crit. Rev. Toxicol. 22, 327-369 (1992).

14. Cain, D. J., Luoma, S. N. \& Wallace, W. G. Linking metal bioaccumulation of aquatic insects to their distribution patterns in a mining-impacted river. Environ. Toxicol. Chem. 23, 1463- 
1473 (2004).

15. Boggs, S. J. Temporal and spatial variability of metal concentrations in fine-grained bed sediments and benthic insect larvae of the Clark Fork river, Montana, U.S.A. (M.Sc. thesis, University of Montana, Missoula, MT, 1994).

16. Vuori, K.-M. \& Kukkonen, J. Metal concentrations in Hydropsyche pellucidula larvae (Trichoptera, Hydropsychidae) in relation to the anal papillae abnormalities and age of exocuticle. Water Res. 30, 2265-2272 (1996).

17. Cain, D. J., Luoma, S. N. \& Axtmann, E. V. Influence of gut content in immature aquatic insects on assessments of environmental metal contamination. Can. J. Fish. Aquat. Sci. 52, 2736-2746 (1995).

18. Buchwalter, D. B. \& Luoma, S. N. Differences in dissolved cadmium and zinc uptake among stream insects: mechanistic explanations. Environ. Sci. Technol. 39, 498-504 (2005).

19. Luoma, S. N. Can we determine the biological availability of sediment-bound trace elements? Hydrobiologia 176/177, 379-396 (1989).

20. Vuori, K.-M. Rapid behavioural and morphological responses of hydropsychid larvae (Trichoptera, Hydropsychidae) to sublethal cadmium exposure. Environ. Pollut. 84, 291-299 (1994).

21. Carls, M. G., Rice, S. D. \& Hose, J. E. Sensitivity of fish embryos to weathered crude oil: Part I. Low-level exposure during incubations causes malformations, genetic damage, and mortality in larval Pacific herring (Clupea pallasi). Environ. Toxicol. Chem. 18, 481-493 (1999).

22. Camargo, J. A. Toxic effects of residual chlorine on larvae of Hydropsyche pellucidula (Trichoptera, Hydropsychidae): A proposal of biological indicator. Bull. Environ. Contam. Toxicol. 47, 261-265 (1991).

23. Tszydel, M., Markowski, M. \& Majecki, J. Larvae of Hydropsyche angustipennis 
(Trichoptera, Hydropsychidae) as indicators of stream contamination by heavy metals in Łódź agglomeration. Zootaxa 4138, 127-138 (2016).

24. Cain, D. J., Buchwalter, D. B. \& Luoma, S. N. Influence of metal exposure history on the bioaccumulation and subcellular distribution of aqueous cadmium in the insect Hydropsyche californica. Environ. Toxicol. Chem. 25, 1042-1049 (2006).

25. Poteat, M. D., Garland T. Jr., Fisher, N. S., Wang, W. X. \& Buchwalter, D. B. Evolutionary patterns in trace metal $(\mathrm{Cd}$ and $\mathrm{Zn})$ efflux capacity in aquatic organisms. Environ. Sci. Technol. 47, 7989-7995 (2013).

26. Girgin, S., Kazanci, N. \& Dügel, M. Relationship between aquatic insects and heavy metals in an urban stream using multivariate techniques. Int. J. Environ. Sci. Technol. 7, 653-664 (2010).

27. Moore, J. N., Luoma, S. N. \& Peters, D. Downstream effects of mine effluent on an intermontane riparian system. Can. J. Fish. Aquat. Sci. 48, 222-232 (1991).

28. Chiba, W. A. C., Passerini, M. D. \& Tundisi, J. G. Metal contamination in benthic macroinvertebrates in a sub-basin in the southeast of Brazil. Braz. J. Biol. 71, 391-399 (2011).

29. Burrows, J. G. \& Whitton, B. A. Heavy metals in water, sediments and invertebrates from a metal-contaminated river free of organic pollution. Hydrobiology 106, 263-273 (1983).

30. Barak, N. A.-E. \& Mason, C. F. Heavy metals in water, sediment and invertebrates from rivers in eastern England. Chemosphere 19, 1709-1714 (1989).

31. Power, E. A. \& Chapman, P. M. Assessing sediment quality in Sediment Toxicity Assessment. (Ann Arbor: Lewis Publishers, 1992).

32. Wichard, W. Morphologische Komponenten bei der Osmoregulation von Trichopteren larven in Proceedings of the $1^{\text {st }}$ International Symposium on Trichoptera (ed. Malicky, H.) 171-177 (Dr Junk, The Hague, 1976). 
33. Darlington, S. T. \& Gower, M. Location of copper in larvae of Plectocnemia conspersa (Curtis) (Trichoptera) exposed to elevated metal concentrations in a mine drainage stream. Hydrobiologia 196, 91-100 (1990).

34. Mason, A. Z. \& Jenkins, K. D. Metal detoxification in aquatic organisms in Metal Speciation and Bioavailability in Aquatic Systems (eds. Tessier, A. \& Turner, D. R.) 479-606 (John Wiley, New York, NY, USA, 1995).

35. Cain, D. J., Carter, J. L., Fend, S. V., Luoma, S. N., Alpers, C. N. \& Taylor, H. E. Metal exposure to a benthic macroinvertebrate, Hydropsyche californica, related to mine drainage in the Sacramento River. Can. J. Fish. Aquat. Sci. 57, 380-390 (2000).

36. Vuori, K.-M. Influence of water quality and feeding habits on the whole-body metal concentrations in lotic trichopteran larvae. Limnology 23, 301-308 (1993).

37. Rainbow, P. Trace metal bioaccumulation: Models, metabolic availability and toxicity. Environ. Int. 33, 576-582 (2007).

38. Trawczyńska, A., Tołoczko, W. \& Niewiadomski, A. The content of trace elements in the water of the upper course of the Bzura River. [abstract in English]. Envir. Protect. Nat. Res. 40, 491-496 (2009).

39. Sakson, G., Brzezinska, A. \& Zawilski, A. Emission of heavy metals from urban catchment into receiving water and possibility of its limitation on the example of Lodz city. Environ. Monit. Assess. 190, 281, 1-15 (2018).

40. Wagner, I., Izydorczyk, K., Drobniewska, A., Frątczak, W. \& Zalewski, M. Inclusion of ecohydrology concept as integral component of systemic in urban water sources management in Proceedings of the International Symposium of New Directions in Urban Water Management 1-9 (Paris, UNESCO Headquarter, 2007).

41. Urbaniak, M., Zieliński, M., Wesołowski, W. \& Zalewski, M. PCBs and Heavy Metals Contamination in Bottom Sediments from Three Reservoirs of Different Catchment 
Characteristics. Polish J. of Environ. Stud. 17, 941-949 (2008).

01 42. Dukowska, M., Michałowicz, J. \& Grzybkowska, M. Influence of natural organic matter and metal accumulation in sediment on riverine macrobenthic assemblages. Pol. J. Ecol. 60, 351362 (2012).

43. Grzybkowska, M., Dukowska, M., Michałowicz, J. \& Leszczyńska, J. Trace metal concentrations in free-ranger, tube-dweller chironomid larvae and a weakly polluted fluvial sediment. Oceanol. Hydrobiol. St. 44, 445-455 (2015).

44. Krantzberg, G. \& Stokes, P. M. Metal Concentrations and Tissues Distribution in Larvae of Chironomus with Reference to X-ray Microprobe Analysis. Arch. Environ. Contam. Toxicol. 19, 84-93 (1990).

45. Buchwalter, D. B., Cain, D. J., Clements, W. H. \& Luoma, S. N. Using biodynamic models to reconcile differences between laboratory toxicity tests and field biomonitoring with aquatic insects. Environ. Sci. Technol. 41, $4821-4828$ (2007).

46. Ratia, H., Vuori, K.-M. \& Oikari, A. Caddis larvae (Trichoptera, Hydropsychidae) indicate delaying recovery of a watercourse polluted by pulp and paper industry. Ecol. Ind. 15, 217226 (2012).

47. Brix, K. V., DeForest, D. K., Burger, M. \& Adams, W. J. Assessing the relative sensitivity of aquatic organisms to divalent metals and their representation in toxicity data sets compared to natural aquatic communities. Hum. Ecol. Risk. Assess. 11, 1139-1156 (2005).

48. Brix, K. V., DeForest, D. K. \& Adams, W. J. The sensitivity of aquatic insects to divalent metals: A comparative analysis of laboratory and field data. Sci. Total. Environ. 409, 41874197 (2011).

49. Lavilla, I., Rodriguez-Liñares, G., Garrido, J. \& Bendicho, C. A biogeochemical approach to understanding the accumulation patterns oftrace elements in three species of dragonfly larvae: evaluation as biomonitors. J. Environ. Monit. 12, 724-730 (2010). 
50. Kheirallah, D. A. Ultrastructure biomarker in Anisops sardeus (Heteroptera: Notonectidae) for the assessment and monitoring of Water Quality of Al-Mahmoudia Canal, Western Part of Nile Delta, Egypt. J. Biosc. Appl. Res. 6, 326- 334 (2015).

51. Chan, I., Tseng, L.-Ch., Kâ, S., Chang, Ch.-F. \& Hwang, J.-S. An Experimental Study of the Response of the Gorgonian Coral Subergorgia suberosa to Polluted Seawater from a Former Coastal Mining Site in Taiwan. Zool. Stud. 51, 27-37 (2012).

52. Borowska, J. \& Pyza, E. Effects of heavy metals on insect immunocompetent cells. J. Insect Physiol. 57, 760-770 (2011).

53. Edington, J. M. \& Hildrew, A. G., (eds.) A key to the caseless caddis larvae of the British Isles with notes on their ecology (Freshwater Biological Association No53, The Ferry House, Cumbria, 1995).

54. Hildrew, A. G. \& Morgan, J. C. The taxonomy of the British Hydropsychidae (Trichoptera). J. Entomol. Sci. 43, 217-229 (1974).

55. Grabka, D., Raczyńska-Żak, M., Czech, K., Słomkiewicz, P. M. \& Jóźwiak, M. A. Modified halloysite as an absorbent for prometryn from aqueous solutions. Appl. Clay Sci. 114, 321329 (2015).

56. Goldstein, J., Newbury, D. E., Joy, D. C., Lyman, C. E., Echlin, P., Lifshin, E., Sawyer, L. \& Michael, J. R. (eds.) Scanning Electron Microscopy and X-ray Microanalysis (Kluwer Academic/Plenum Publishhers, New York, 2003).

57. Biehl, L. \& Landgrebe, D. MultiSpec a tool for multispectral-hyperspectral image data analysis. Comput. Geosci. 28, 1153-1159 (2002).

58. StatSoft Inc., STATISTICA (data analysis software system) version 10. (2011) www.statsoft.com

59. Sokal, R. R. \& Rohlf, F. (eds.) Biometry: the principles and practice of statistics in biological research (WH Freeman \& Co., San Francisco, ed. 4, 2005). 
60. Elliott, J. M. (ed.) Some methods for the statistical analysis of samples of benthic invertebrates (Freshwater Biological Association, Westmorland, UK, Ambleside, 2 ed., 1977).

61. Zar, J. H. (ed.) Biostatistical analysis (Prentice Hall, Upper Saddle River, 4 ed., 1999).

\section{Acknowledgements}

We are grateful to Marcin Markowski for providing help in the laboratory analysis. We thank Łukasz Głowacki for the language edition of our manuscript. We would also like to thank Gordon Copp for valuable comments and suggestions on the previous version of the manuscript. The study was financed by the Mayor of Łódź from the budget of The City of Lodz (research project No. ED.VII.4346 G-17/2009 and 2010). The study was supported also by the internal Grant from the University of Lodz. Author contributions: M.T. - Conceptualization, Methodology, Formal analysis, Investigation, Resources, Figures, Writing - Original Draft, Supervision; D.B. Conceptualization, Writing - Original Draft, Writing - Review \& Editing; J.P. - Methodology, Writing - Review \& Editing; M.J. - Methodology, Resources, Figures. The authors declare no competing interest.

\section{Figures}

Fig. 1 Study area and location of the sampling sites. Graphic symbols show the type of pollution being the main source of heavy metals in the studied rivers. Sampling sties were encoded as follows: the first letter of the code is the name of a stream (B - Bzura, S - Sokołówka, L - Łódka, O - Olechówka and G - Grabia), the next is a number of the station, the third mark means the degree of riverbed naturalness $(\mathrm{N}$ - natural, $\mathrm{R}$ - regulated, I -isolation by covering the bottom with concrete and/or bricks). The last letter indicated the relation of the river to the municipial sewage system (C- stream included in the sewage system, $\mathrm{S}$ - stream in areas of 
separate sewage system).
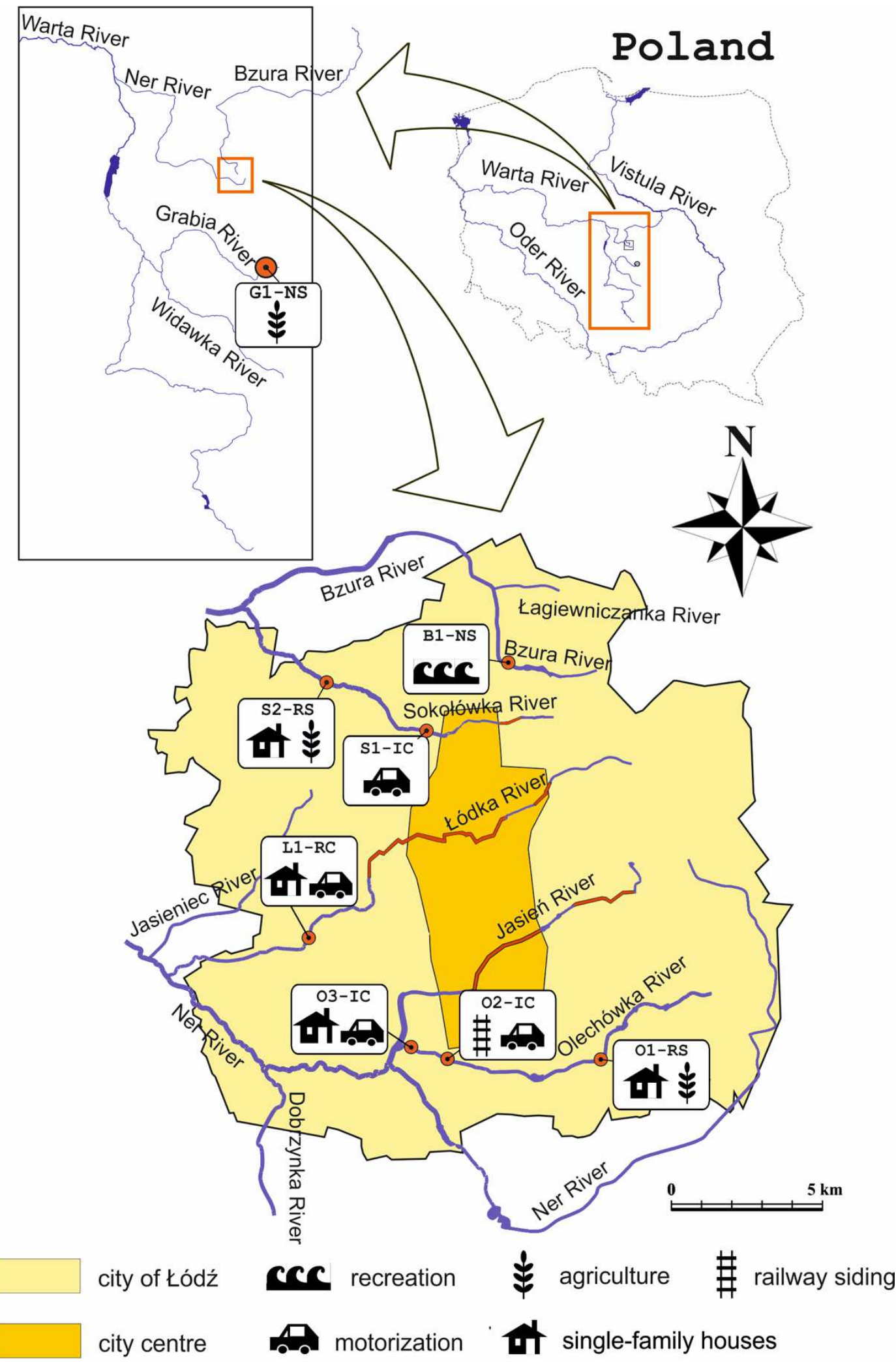

sections of the streams hidden underground and collected with sewage from storm drains 
77 Fig. 2. Location of anal papillae and their abnormalities. Sublethal effects were analyzed in 78 larvae of $H$. angustipennis, where (a) PALE - anal papillae visible, (b) COLRAP+/- one to four 79 anal papillae partially darkened, (c) COLRAP - anal papillae completely darkened.

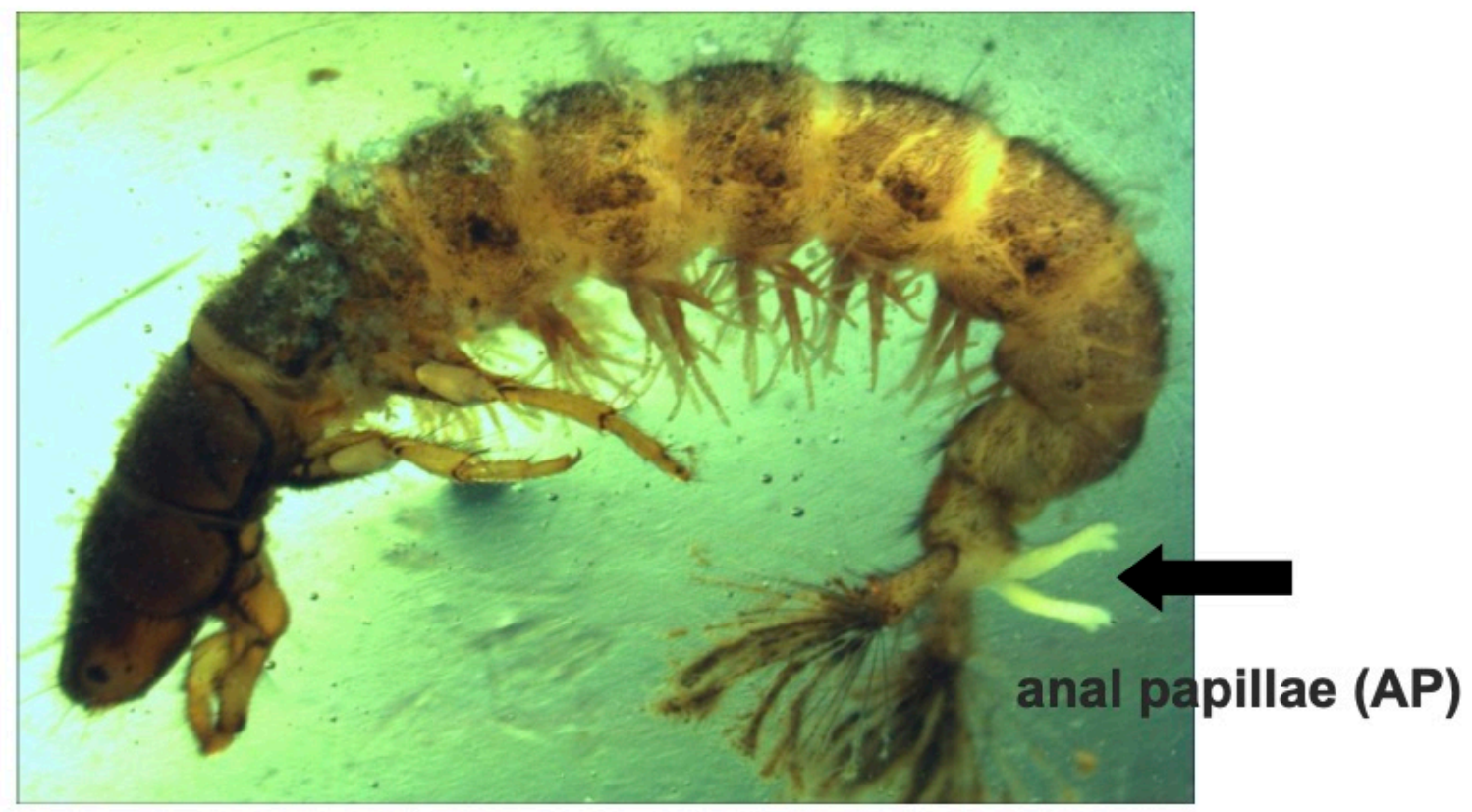

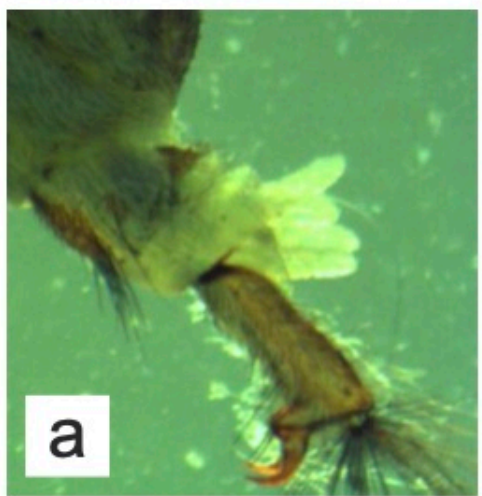

PALE

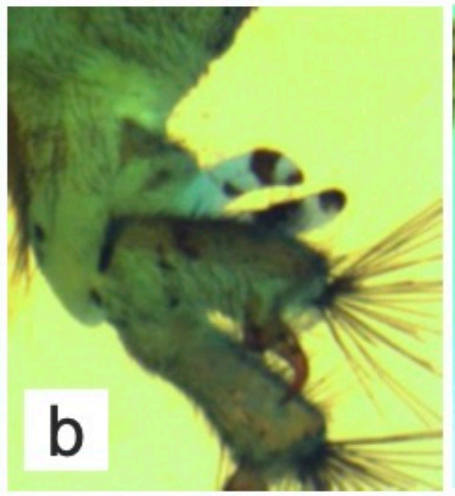

COLRAP+/-

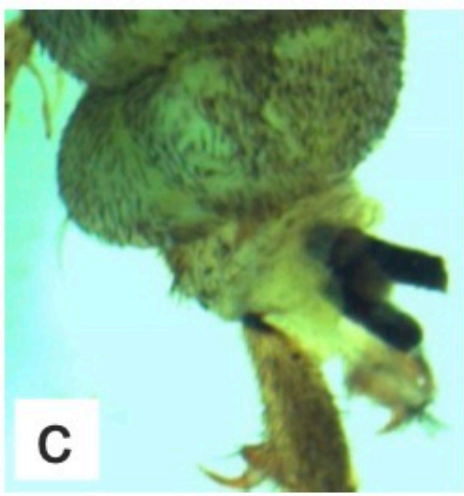

COLRAP 
84 Fig. 3. Measuring points of $\boldsymbol{H}$. angustipennis anal papillae. (a) Upper photo was taken with the 85 digital camera, (b) lower photo comes from SEM microscopy.
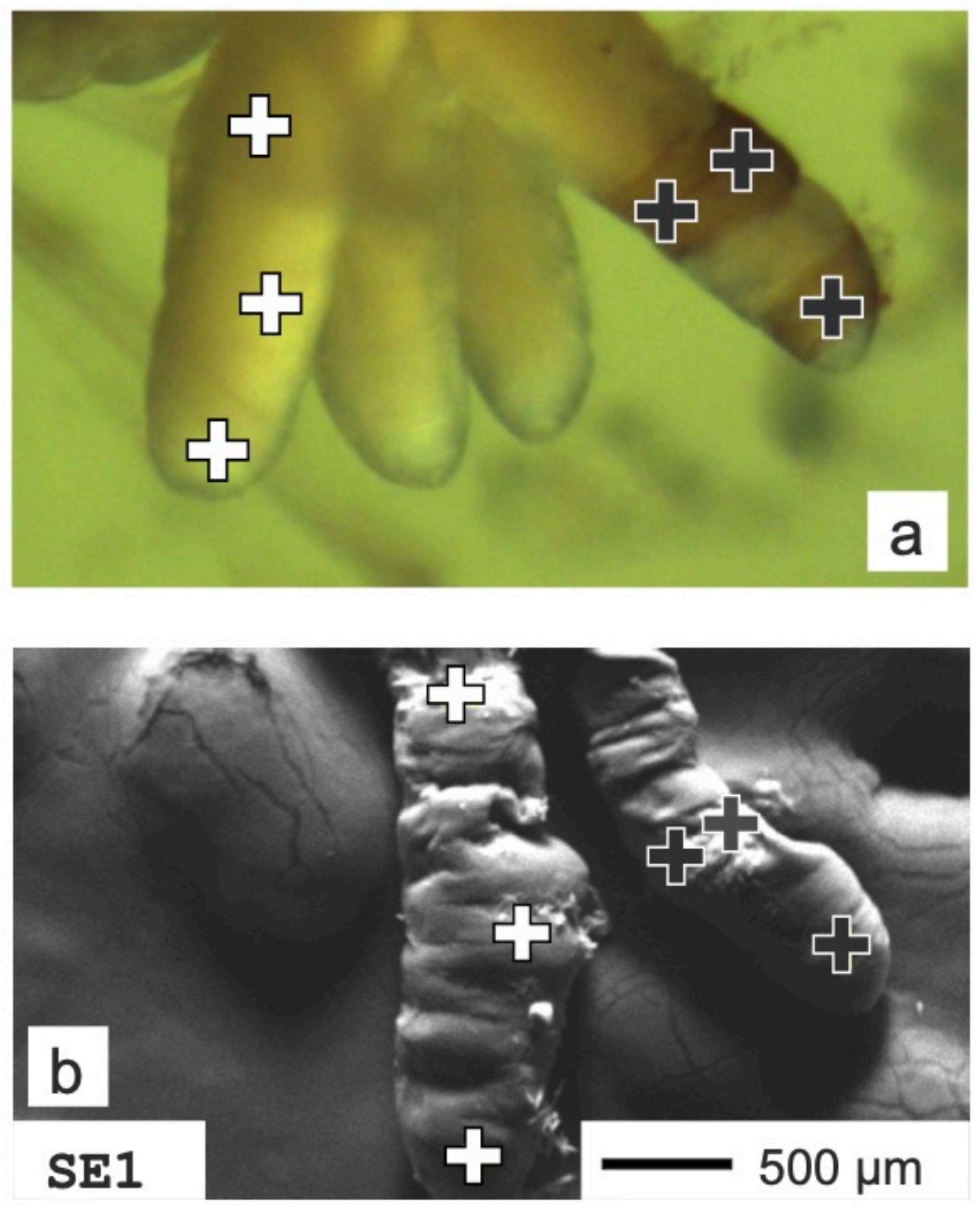
90 (b) spectra presenting the chemical composition of most frequently observed elements. Wt $\%$ -

91 weight ratio; $A t \%$ - atomic ratio.

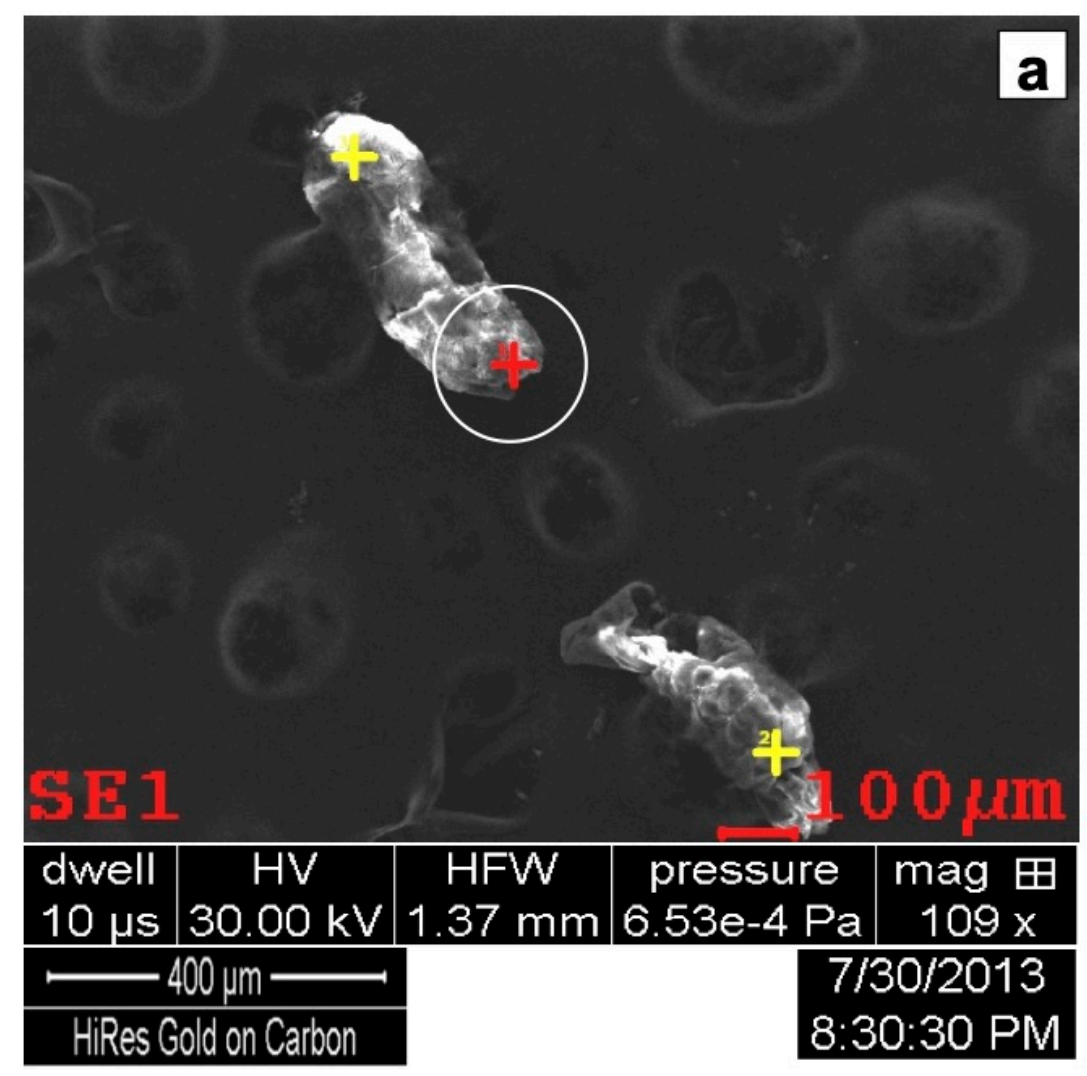

KV:28.47 TILT: 0.00 TAKE-OFF:36.73 AMPT:128 DETECTOR TYPE :SD APOLLOX RESOLUTIQ:127.99
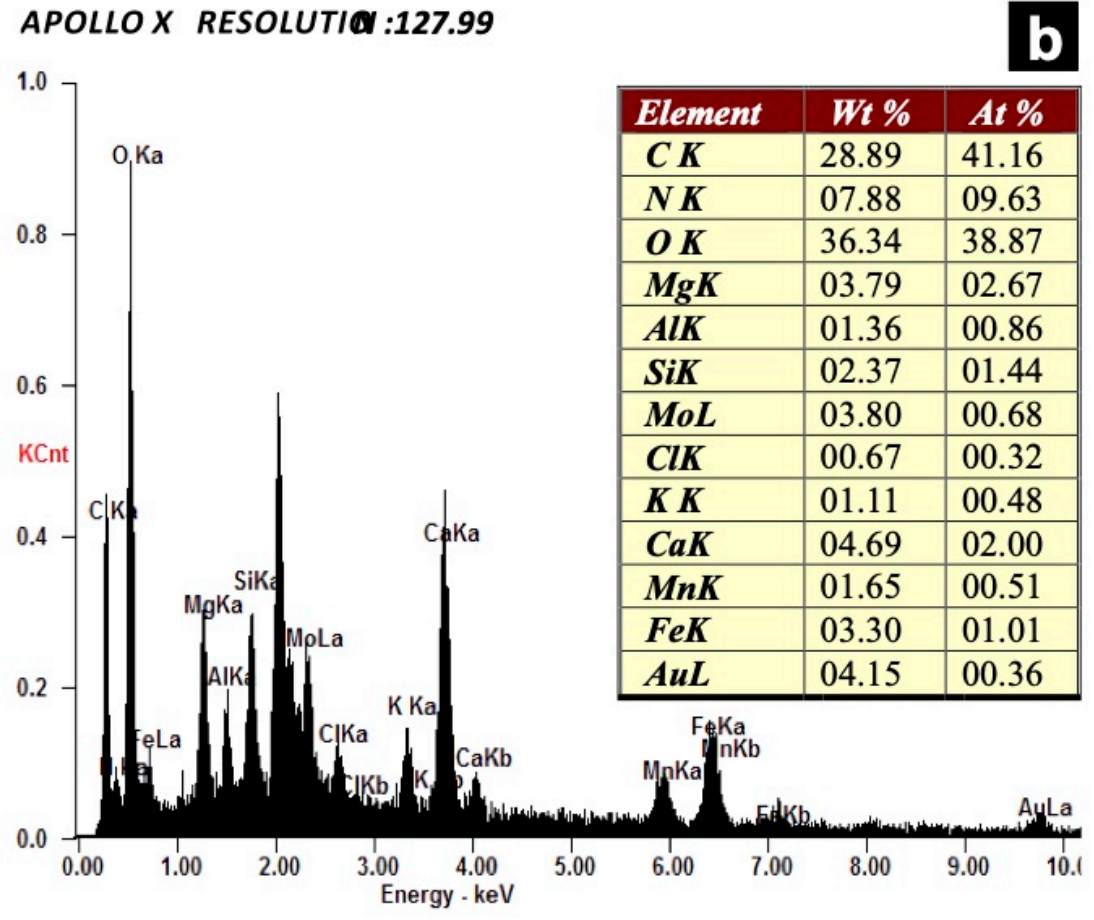
$94 \quad$ anal papillae at the sampling sites.

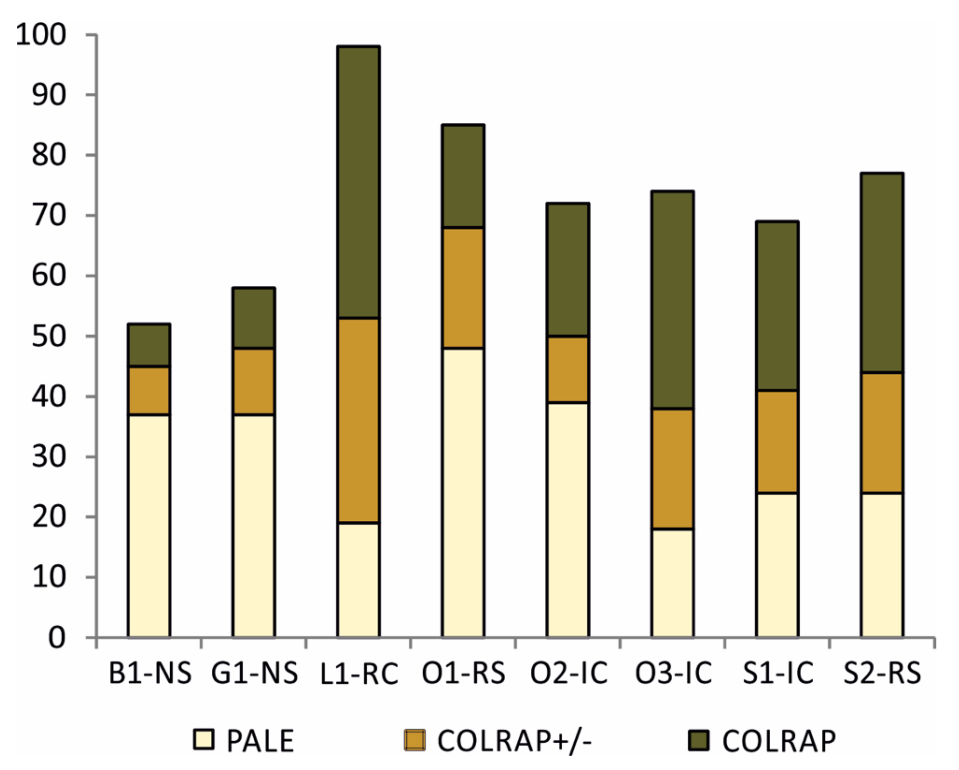

96 Fig. 6. Mean values of the percentage [\%] domination of heavy metals in anal papillae, depending on 97 the degree of their deformations.

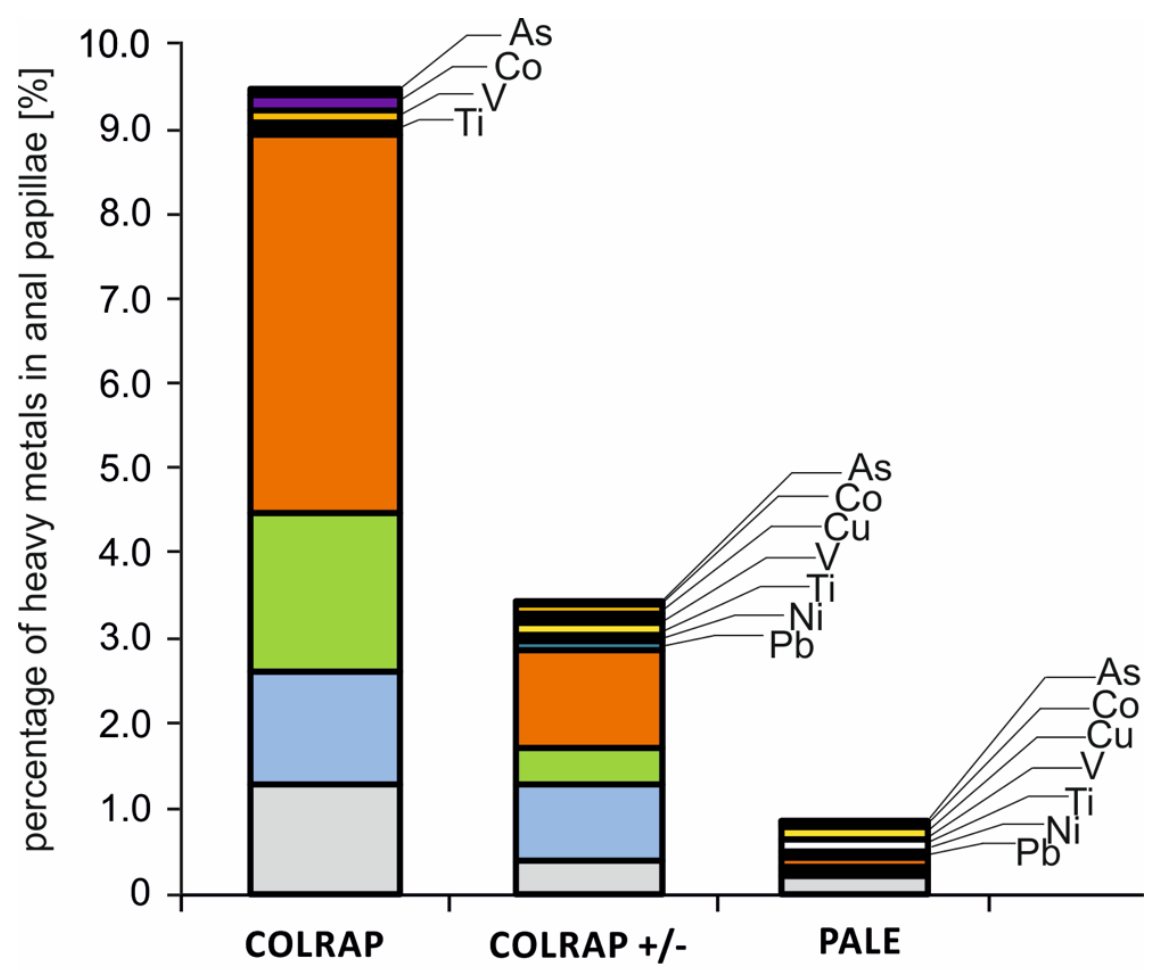

$\square$ Al $\square$ Mo $\square \mathrm{Mn} \quad \square \mathrm{Fe} \quad \square \mathrm{Pb} \quad \square \mathrm{Ni}$ 


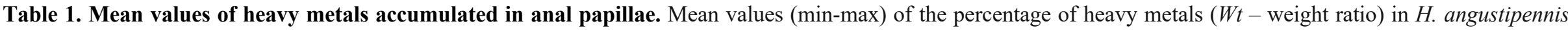
anal papillae at the sampling sites. F values represent the results of one-way ANOVA test. Significant differences $(p)$ among sampling sites were marked in bold.

\begin{tabular}{|c|c|c|c|c|c|c|c|c|c|c|c|c|}
\hline $\begin{array}{l}\text { sampling } \\
\text { sites }\end{array}$ & $\begin{array}{c}\mathrm{Fe} \\
{[\%]}\end{array}$ & $\begin{array}{l}\text { Mo } \\
{[\%]}\end{array}$ & $\begin{array}{l}\mathrm{Mn} \\
{[\%]}\end{array}$ & $\begin{array}{l}\mathrm{Al} . \\
{[\%]}\end{array}$ & $\begin{array}{l}\mathrm{Cu} \\
{[\%]}\end{array}$ & $\begin{array}{l}\mathrm{Pb} \\
{[\%]}\end{array}$ & $\begin{array}{l}\mathrm{Ni} \\
{[\%]}\end{array}$ & $\begin{array}{l}\mathrm{Co} \\
{[\%]}\end{array}$ & $\begin{array}{l}\text { As } \\
{[\%]}\end{array}$ & $\begin{array}{c}\mathrm{Ti} \\
{[\%]}\end{array}$ & $\begin{array}{c}\mathrm{V} \\
{[\%]}\end{array}$ & $\begin{array}{c}\text { Total } \\
{[\%]}\end{array}$ \\
\hline B1-NS & $\begin{array}{c}0.06 \\
(0-1.14)\end{array}$ & $\begin{array}{c}0.17 \\
(0-3.14)\end{array}$ & $\begin{array}{c}0.14 \\
(0-1.94)\end{array}$ & $\begin{array}{c}0.09 \\
(0-0.73)\end{array}$ & 0 & $\begin{array}{c}0.14 \\
(0-2.45)\end{array}$ & 0 & 0 & $\begin{array}{c}0.05 \\
(0-0.78)\end{array}$ & 0 & 0 & $\begin{array}{c}0.64 \\
(0-10.18)\end{array}$ \\
\hline G1-NS & 0 & 0 & 0 & $\begin{array}{c}0.04 \\
(0-0.24)\end{array}$ & 0 & 0 & 0 & 0 & 0 & 0 & 0 & $\begin{array}{c}0.04 \\
(0-0.24)\end{array}$ \\
\hline L1-RC & $\begin{array}{c}3.21 \\
(0-11.24)\end{array}$ & $\begin{array}{c}2.21 \\
(0-7.37)\end{array}$ & $\begin{array}{c}2.86 \\
(0-7.27)\end{array}$ & $\begin{array}{c}1.00 \\
(0-3.91)\end{array}$ & $\begin{array}{c}0.37 \\
(0-2.23)\end{array}$ & 0 & 0 & $\begin{array}{c}0.13 \\
(0-0.76)\end{array}$ & 0 & $\begin{array}{c}0.04 \\
(0-0.24)\end{array}$ & $\begin{array}{c}0.03 \\
(0-0.15)\end{array}$ & $\begin{array}{c}9.84 \\
(0-33.17)\end{array}$ \\
\hline O1-RS & $\begin{array}{c}0.09 \\
(0-0.71)\end{array}$ & $\begin{array}{c}0.21 \\
(0-1.64)\end{array}$ & $\begin{array}{c}0.13 \\
(0-1.04)\end{array}$ & $\begin{array}{c}0.05 \\
(0-0.36)\end{array}$ & 0 & $\begin{array}{c}0.06 \\
(0-0.49)\end{array}$ & 0 & 0 & 0 & 0 & 0 & $\begin{array}{c}0.53 \\
(0-4.18)\end{array}$ \\
\hline O2-IC & $\begin{array}{c}1.92 \\
(0-9.44)\end{array}$ & $\begin{array}{c}0.30 \\
(0-2.27)\end{array}$ & $\begin{array}{c}0.04 \\
(0-0.4)\end{array}$ & $\begin{array}{c}0.78 \\
(0-1.81)\end{array}$ & $\begin{array}{c}0.70 \\
(0-5.90)\end{array}$ & $\begin{array}{c}0.36 \\
(0-2.85)\end{array}$ & $\begin{array}{c}0.51 \\
(0-4.56)\end{array}$ & $\begin{array}{c}0.04 \\
(0-0.4)\end{array}$ & $\begin{array}{c}0.04 \\
(0-0.4)\end{array}$ & $\begin{array}{c}0.04 \\
(0-0.4)\end{array}$ & $\begin{array}{c}0.04 \\
(0-0.4)\end{array}$ & $\begin{array}{c}4.79 \\
(0-28.83)\end{array}$ \\
\hline O3-IC & $\begin{array}{c}1.60 \\
(0-5.77)\end{array}$ & $\begin{array}{c}4.51 \\
(0-12.30)\end{array}$ & $\begin{array}{c}0.13 \\
(0-0.9)\end{array}$ & $\begin{array}{c}0.55 \\
(0.17-1.78)\end{array}$ & 0 & 0 & 0 & 0 & 0 & 0 & 0 & $\begin{array}{c}6.79 \\
(0.17-10.75)\end{array}$ \\
\hline S1-IC & $\begin{array}{c}6.62 \\
(0-13.24)\end{array}$ & 0 & 0 & $\begin{array}{c}1.40 \\
(0-2.79)\end{array}$ & 0 & 0 & 0 & 0 & 0 & 0 & 0 & $\begin{array}{c}8.01 \\
(0-16.03)\end{array}$ \\
\hline S2-RS & $\begin{array}{c}0.70 \\
(0-2.11) \\
\end{array}$ & 0 & $\begin{array}{c}1.11 \\
(0-3.33) \\
\end{array}$ & $\begin{array}{c}0.16 \\
(0-0.47) \\
\end{array}$ & 0 & 0 & 0 & 0 & 0 & 0 & 0 & $\begin{array}{c}1.97 \\
(0-5.91) \\
\end{array}$ \\
\hline $\mathrm{F}_{\text {ANOVA }}$ & 3.3615 & 3.6353 & 6.1144 & 2.9982 & 0.8409 & 0.4979 & 0.7718 & 1.0660 & 0.2844 & 0.7827 & 0.7423 & 5.7109 \\
\hline $\mathrm{p}_{\text {ANOVA }}$ & 0.0050 & 0.0029 & 0.0000 & 0.0103 & 0.5588 & 0.8316 & 0.6135 & 0.3986 & 0.9572 & 0.6048 & 0.6374 & 0.0001 \\
\hline
\end{tabular}





\section{Figures}

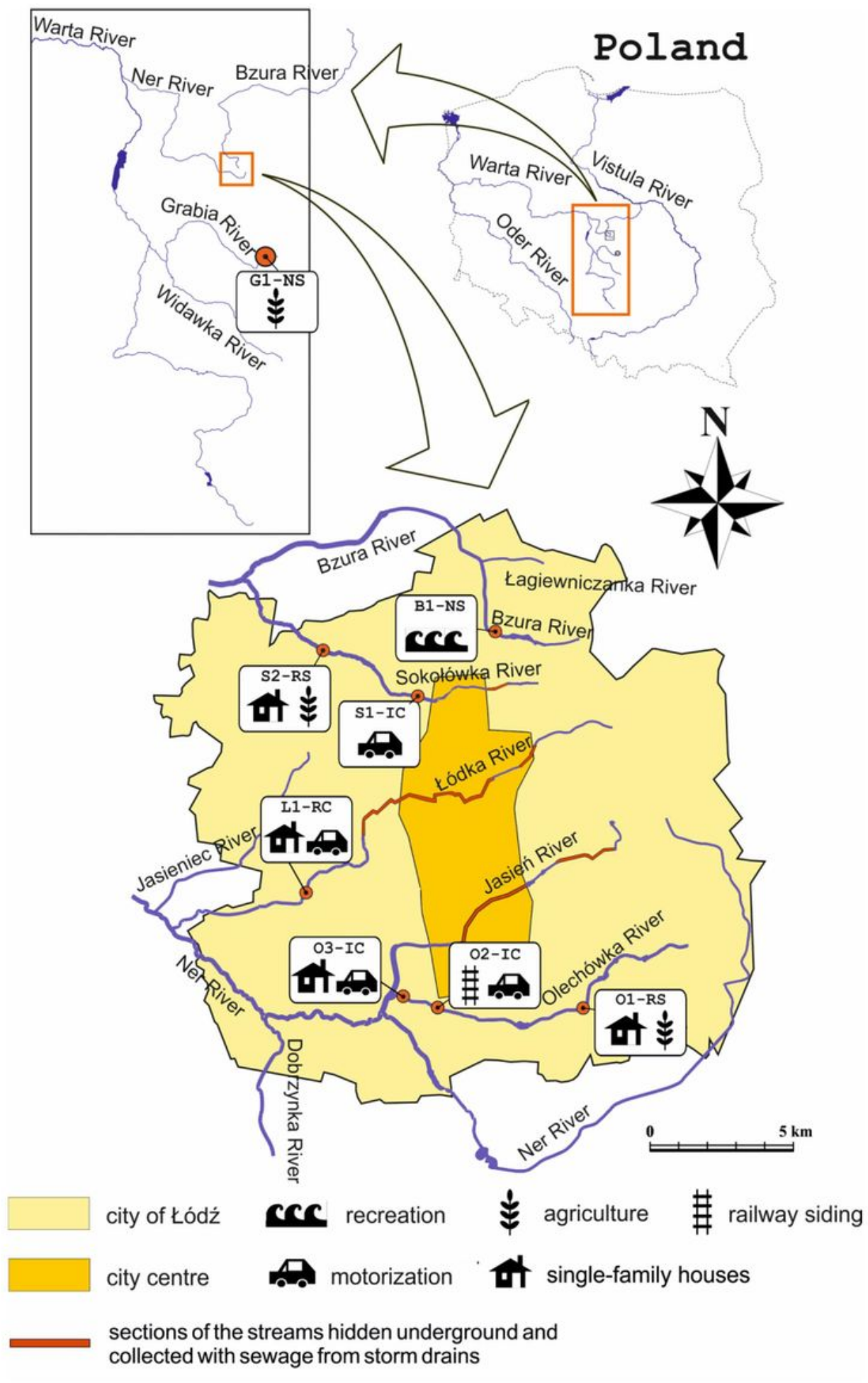

Figure 1

Study area and location of the sampling sites. Graphic symbols show the type of pollution being the main source of heavy metals in the studied rivers. Sampling sties were encoded as follows: the first letter of the code is the name of a stream (B - Bzura, S - Sokołówka, L - Łódka, O - Olechówka and G - 
Grabia), the next is a number of the station, the third mark means the degree of riverbed naturalness ( $\mathrm{N}$ natural, $\mathrm{R}$ - regulated, I -isolation by covering the bottom with concrete and/or bricks). The last letter indicated the relation of the river to the municipial sewage system (C-stream included in the sewage system, S - stream in areas of separate sewage system). Note: The designations employed and the presentation of the material on this map do not imply the expression of any opinion whatsoever on the part of Research Square concerning the legal status of any country, territory, city or area or of its authorities, or concerning the delimitation of its frontiers or boundaries. This map has been provided by the authors.

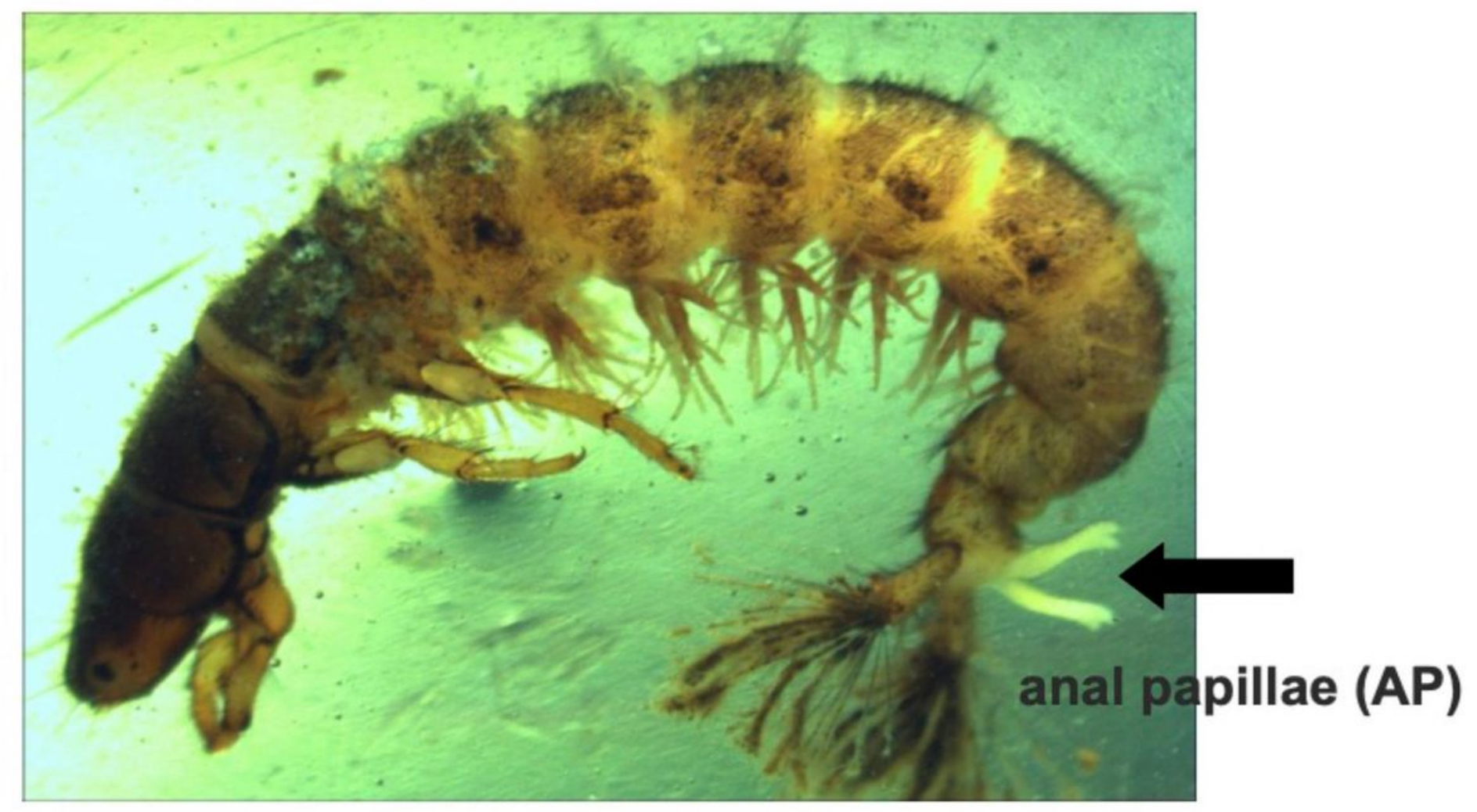

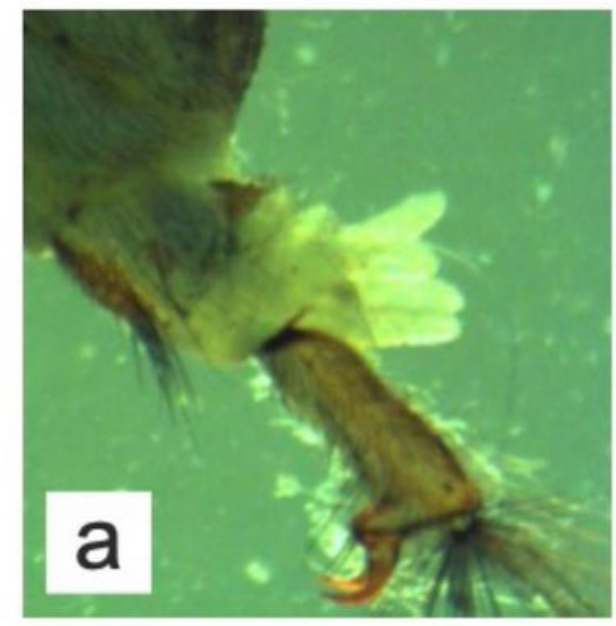

PALE

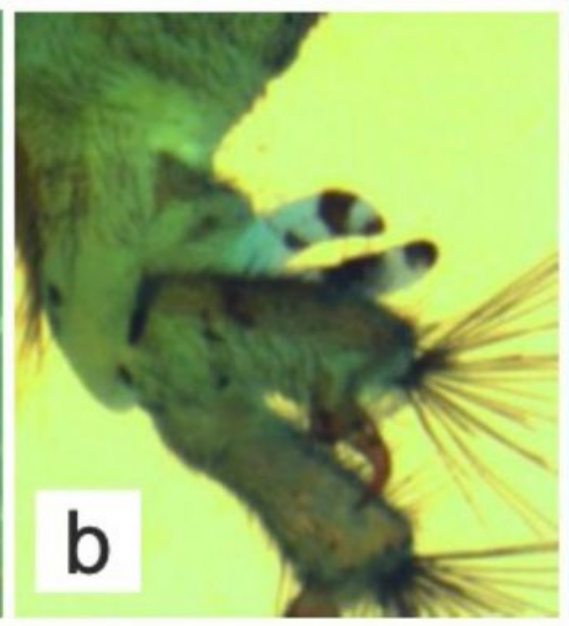

COLRAP+/-

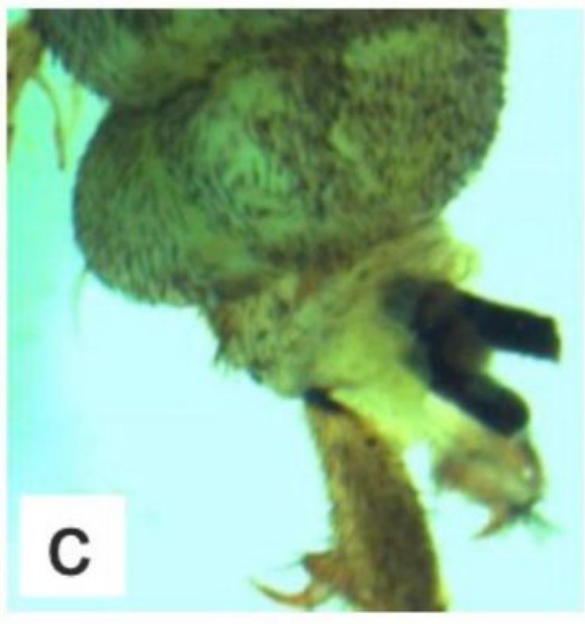

COLRAP

Figure 2 
Location of anal papillae and their abnormalities. Sublethal effects were analyzed in larvae of $\mathrm{H}$. angustipennis, where (a) PALE - anal papillae visible, (b) COLRAP+/- one to four anal papillae partially darkened, (c) COLRAP - anal papillae completely darkened.
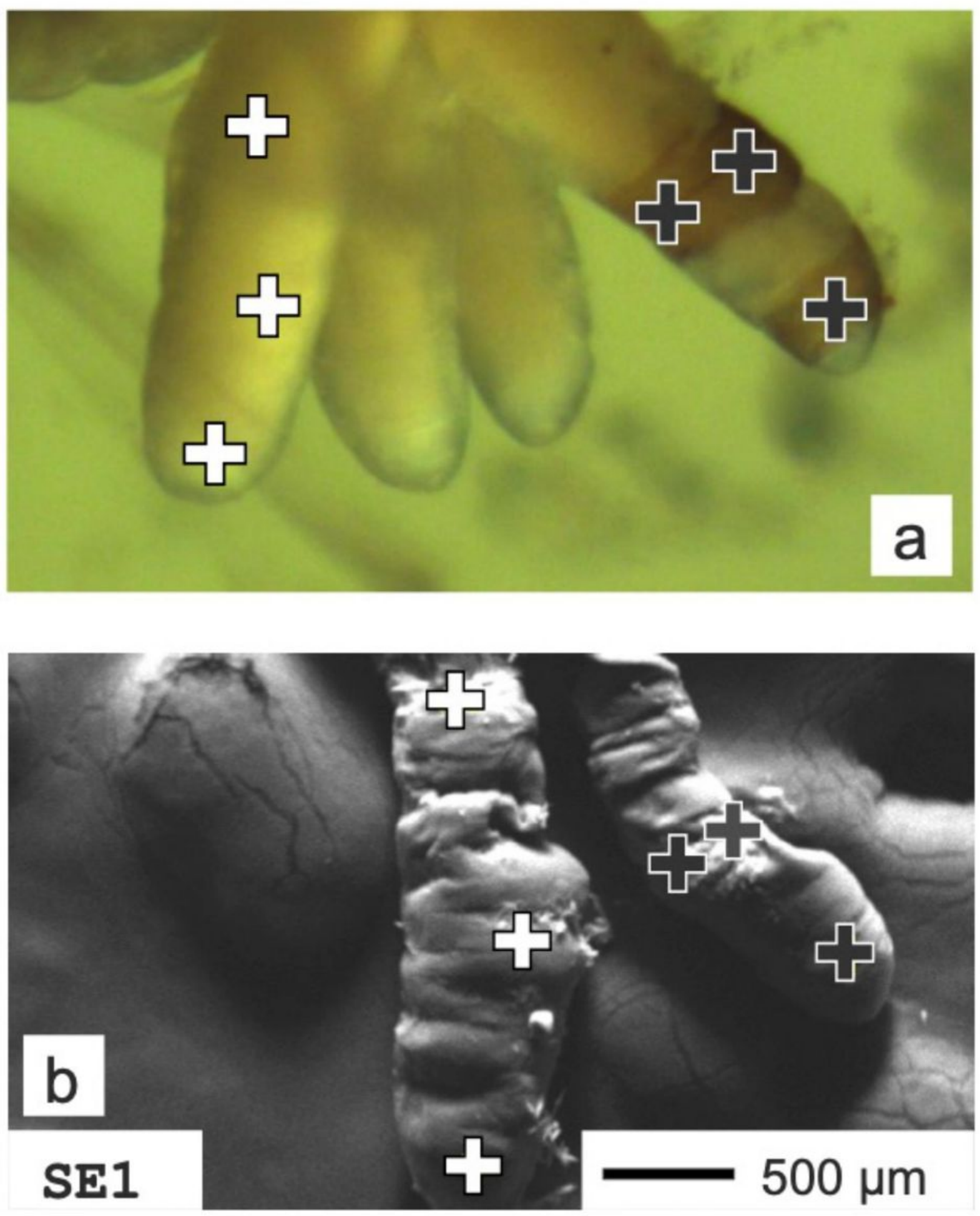

Figure 3

Measuring points of $\mathrm{H}$. angustipennis anal papillae. (a) Upper photo was taken with the digital camera, (b) lower photo comes from SEM microscopy. 

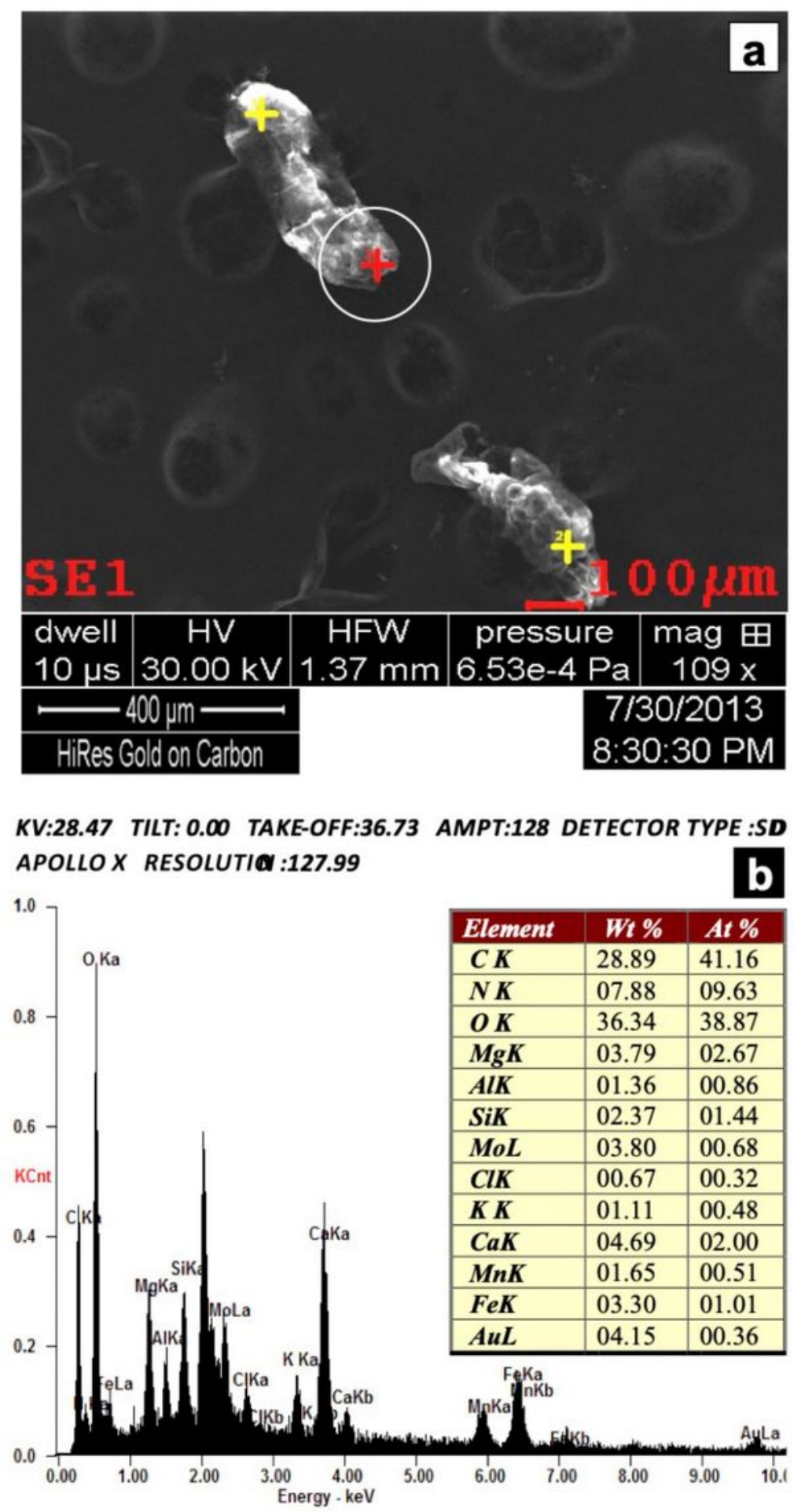

\section{Figure 4}

SEM-EDS photomicrographs of $\mathrm{H}$. angustipennis anal papillae. (a) Measuring point, (b) spectra presenting the chemical composition of most frequently observed elements. Wt \% - weight ratio; At \% atomic ratio. 


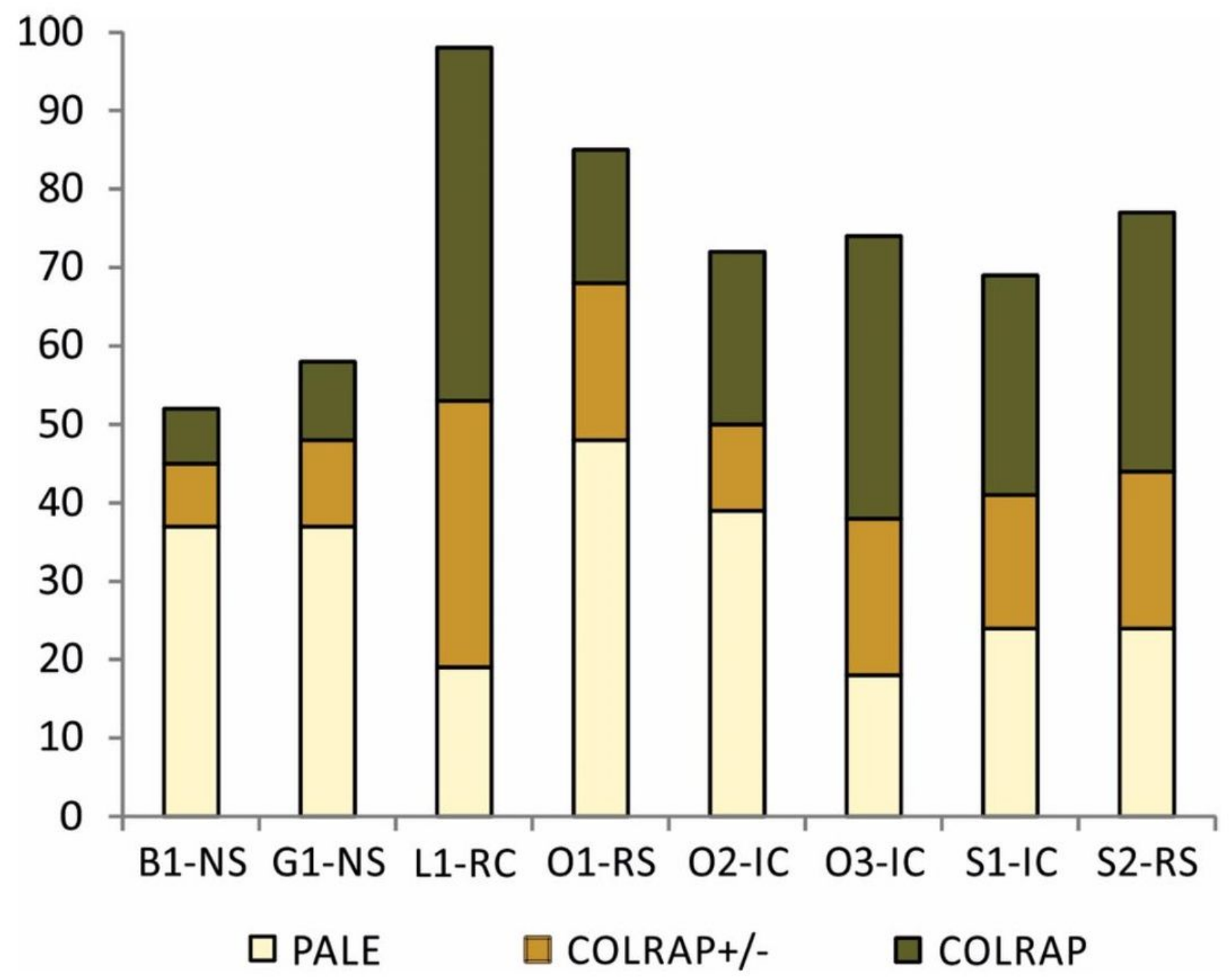

Figure 5

Mean values of the percentage [\%] of larvae with abnormalities of $\mathrm{H}$. angustipennis anal papillae at the sampling sites. 


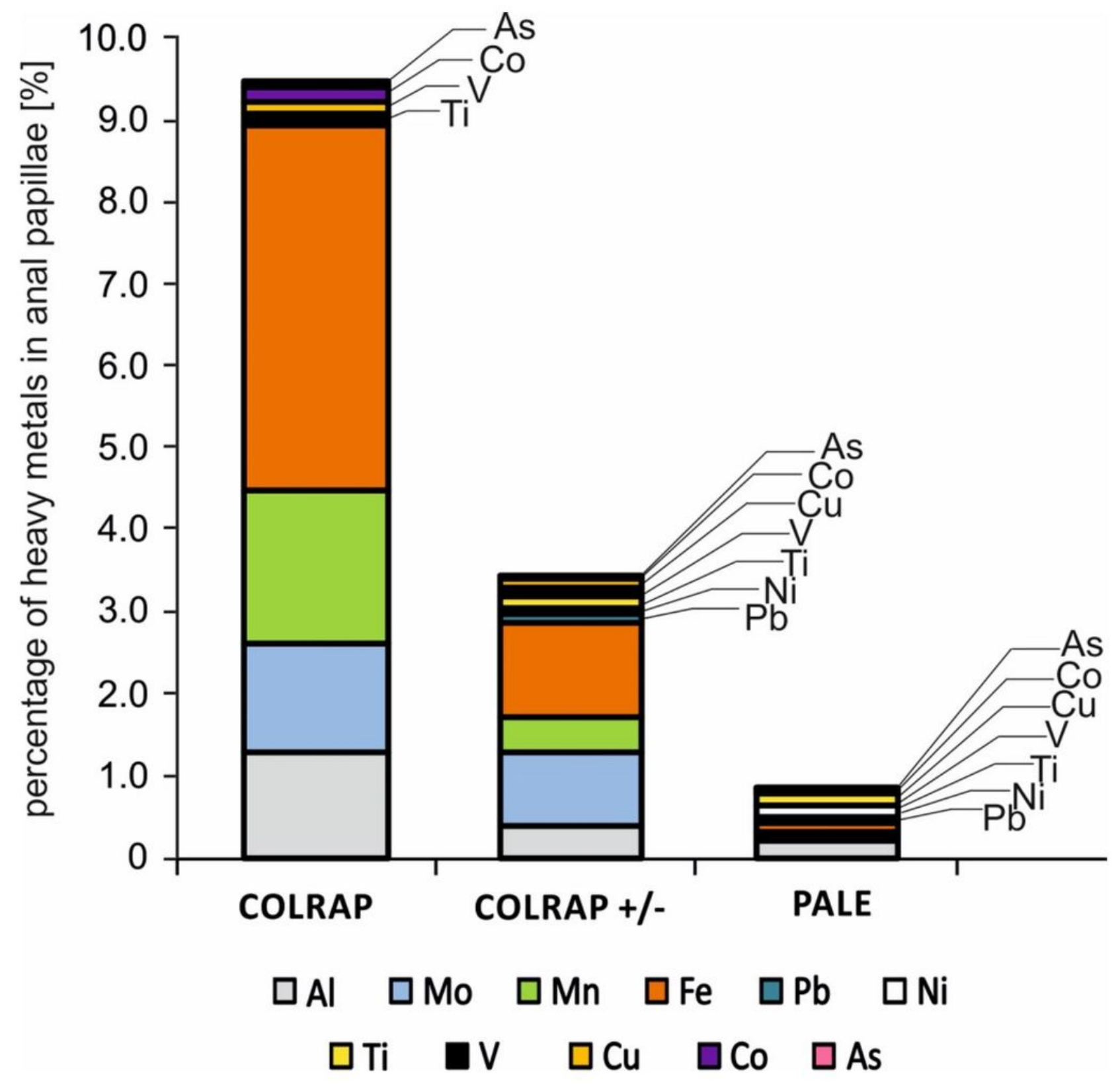

Figure 6

Mean values of the percentage [\%] domination of heavy metals in anal papillae, depending on the degree of their deformations. 